\title{
CARBON IN FOREST SPECIES OF THE ATLANTIC FOREST AS AN INDICATOR OF STOCKS AND QUALITY
}

\author{
Ane Cristine Fortes da Silva ${ }^{1 *}$, Fernando José Freire ${ }^{2}$, César Henrique Alves Borges ${ }^{3}$, Emmanoella Costa \\ Guaraná Araujo ${ }^{4}$, Ernandes Macedo da Cunha Neto ${ }^{4}$, Carlos Roberto Sanquetta ${ }^{5}$ \\ ${ }^{1 *}$ Instituto Federal da Paraíba, Princesa Isabel, Paraíba, Brasil - ane.silva@ifpb.edu.br \\ ${ }^{2}$ Universidade Federal Rural de Pernambuco, Departamento de Agronomia, Recife, Pernambuco, Brasil - fernando.freire@ufrpe.br \\ ${ }^{3}$ Universidade Federal Rural de Pernambuco, Programa de Pós-Graduação em Ciências Florestais, Recife, Pernambuco, Brasil - \\ cesarhenrique27@yahoo.com.br \\ ${ }^{4}$ Universidade Federal do Paraná, Programa de Pós-Graduação em Ciências Florestais, Curitiba, Paraná, Brasil - \\ manuguarana@gmail.com / netomacedo878@gmail.com \\ ${ }^{5}$ Universidade Federal do Paraná, Departamento de Ciências Florestais, Curitiba, Paraná, Brasil - carlossanquetta@gmail.com
}

Received for publication: 11/02/2020 - Accepted for publication: 22/04/2020

\begin{abstract}
Resumo
Carbono em espécies florestais da mata atlântica como indicador de estoques e qualidade. Objetivou-se quantificar os teores de carbono (C) nos reservatórios da biomassa vegetal de diferentes espécies em um fragmento de Floresta Atlântica no Nordeste do Brasil. Foram selecionadas dez espécies de maior densidade absoluta. Foram amostradas biomassa dos compartimentos folhas e lenho de cada uma das espécies para determinação do teor de $\mathrm{C}$. Houve diferença nos teores foliares de $\mathrm{C}$ entre as espécies. O teor de $\mathrm{C}$ nas folhas das espécies variou entre 451,4 e $456,7 \mathrm{~g} \mathrm{~kg}^{-1}$. O teor de $\mathrm{C}$ do lenho das espécies variou entre 451,7 e $456,8 \mathrm{~g} \mathrm{~kg}^{-1}$. O grupo formado pelas famílias Burseraceae, Moraceae e Sapotaceae apresentou maiores teores médios de $\mathrm{C}$ nas folhas. A família Burseraceae apresentou maior teor médio de $\mathrm{C}$ no lenho das espécies. A utilização do teor de carbono pré-estabelecido (500 $\mathrm{g} \mathrm{kg}^{-1}$ ) pode gerar estimativas inconsistentes e superior aos valores reais para as espécies e famílias em ambiente de Floresta Atlântica. Sugere-se que nas estimativas de estoques de C sejam utilizados teores específicos para espécies e/ou famílias, contribuindo para uma estimativa mais realista dos padrões de estocagem de $\mathrm{C}$ na biomassa aérea das espécies da Floresta Atlântica.

Palavras-chave: Concentração de carbono; Sequestro de carbono; Floresta tropical úmida.
\end{abstract}

\begin{abstract}
The objective is to quantify the carbon content $(\mathrm{C})$ of the reservoirs of plant biomass of different species in a fragment of the Atlantic Forest in Northeast Brazil. Ten species of high absolute density were selected. We sampled biomass from the leaf and wood compartments of each species to determine the $\mathrm{C}$ content. There was a difference in leaf $\mathrm{C}$ levels between species. The $\mathrm{C}$ content in leaves of species varied between 451.4 and $456.7 \mathrm{~g} \mathrm{~kg}^{-1}$. The $\mathrm{C}$ content of the wood of species varied between 451.7 and $456.8 \mathrm{~g}$ $\mathrm{kg}^{-1}$. The group formed by the families Burseraceae, Moraceae, and Sapotaceae showed higher average levels of $\mathrm{C}$ in leaves. The Burseraceae family had the highest average $\mathrm{C}$ content in the species' wood. The use of a pre-established carbon content $\left(500 \mathrm{~g} \mathrm{~kg}^{-1}\right)$ may generate inconsistent estimates higher than the real values for the species and families in an Atlantic Forest environment. We suggest that $\mathrm{C}$ stock estimates use specific levels for species and/or families, contributing to a more realistic estimate of $\mathrm{C}$ storage patterns in the shoot biomass of Atlantic Forest species.

Keywords: Carbon concentration; Carbon sequestration; Tropical Rainforest.
\end{abstract}

\section{INTRODUCTION}

Over the last centuries, the concentration of $\mathrm{C}$ in the atmosphere has increased mainly due to the acceleration of industrial activities and agricultural expansion resulting from the deforestation of forest areas (PEARSON et al., 2017). Such increase in $\mathrm{C}$, mainly in the form of $\mathrm{CO}_{2}$ and other gases, has intensified the greenhouse effect and favored global warming.

In Brazil, the intense forest degradation caused by anthropic disturbances reduced the Atlantic Forest to $\sim 15 \%$ of its original size (FUNDAÇÃO SOS MATA ATLÂNTICA, 2018), reflecting negatively in many scenarios, mainly in the capture and emissions of carbon dioxide $\left(\mathrm{CO}_{2}\right)$ and carbon storage $(\mathrm{C})$.

Tropical forests are known to play an important role in the global $\mathrm{C}$ cycle. They store approximately $46 \%$ of the world's terrestrial $\mathrm{C}$ reserve and approximately $12 \%$ of the soil reserve, act as a reservoir, and function as a constant sink for atmospheric C (VASHUM; JAYAKUMAR, 2012).

However, $\mathrm{C}$ stock estimates are determined by multiplying the total dry biomass of plants and the $\mathrm{C}$ concentrations in plant tissues of different species. In the Brazilian Atlantic Forest, few data are available on 
the variability of $\mathrm{C}$ levels in different plant tissues and species, which leads to the use of pre-established $\mathrm{C}$ concentrations.

The fixed value of $50 \%\left(500 \mathrm{~g} \mathrm{~kg}^{-1}\right)$ for $\mathrm{C}$ content in plant tissues is suggested in regional and global carbon stock studies (IPCC, 2006, LEWIS et al., 2009, BRAUN et al., 2016, SAATCHI et al., 2011; COLLINS et al., 2019). However, it may not represent actual levels in tropical forests. In addition, most studies do not consider the differences between $\mathrm{C}$ concentrations in different plant organs, further causing errors in estimates of global stocks of C. Ma et al. (2018) showed that a $1 \%$ change in the concentration of C in wood tissues may lead to a variation of $\sim 7 \mathrm{Pg}$. in the global stocks of $\mathrm{C}$ in the vegetation, making it difficult to assess the global $\mathrm{C}$ sequestration.

For this reason, it is essential to quantify the levels of $\mathrm{C}$ in the biomass of tropical forest species, especially those of the Atlantic Forest, which is under intense pressure by human actions and stores large amounts of the global C (PEARSON et al., 2017). With this information at hand it is possible to understand better the processes that affect the balance of the $\mathrm{C}$ stock in this forest and identify the magnitude of impacts of its degradation in the context of climate change.

It is assumed that this information will also subsidize environmental projects that help to mitigate the effects of anthropic and/or natural processes on $\mathrm{C}$ storage and to determine key species for the conservation and sequestration of $\mathrm{C}$. Thus, the objective of this study is to determine the $\mathrm{C}$ levels in the leaf and wood compartments of ten species of high absolute density in a fragment of tropical Rainforest in Northeast Brazil.

\section{MATERIAL AND METHODS}

\section{Description of the study area}

The study was carried out in a tropical Rainforest ecosystem located in the state of Pernambuco. Table 1 shows the edaphoclimatic characterization and the geographic location of the study area.

Table 1. Location and characteristics of the forest fragment.

Tabela 1. Localização e características do fragmento florestal.

\begin{tabular}{lc}
\hline & Tropical Rainforest \\
\hline Location & Recife, Pernambuco, Brazil \\
Area & $\left(8^{\circ} 04^{\prime} \mathrm{S}-34^{\circ} 57^{\prime} \mathrm{W}\right)$ \\
Altitude & $28 \mathrm{ha}$ \\
Climate & $38 \mathrm{~m}$ \\
& As' \\
Rainfall & Tropical with dry winters ${ }^{(1)}$ \\
Temperature & $\sim 1,500$ mm year $^{-1}(2)$ \\
Domain & $25.8^{\circ} \mathrm{C}^{\prime}$ \\
Phytophysiognomy & Lowland Dense Ombrophilous Forest \\
Soil classification & Atlantic Forest \\
Topography & Dystrophic Yellow Latosol ${ }^{(3)}$ \\
Absolute density & Predominantly flat \\
Number of species & 970 ind. ha ${ }^{-1}$ \\
\hline
\end{tabular}

${ }^{(1)}$ Alvares et al. (2014); (2) Reboita et al. (2010); (3)Santos et al. (2013).

Ten species of high absolute density were selected based on the floristic and phytosociological survey of adult individuals previously carried out by Espig et al. (2008), which together represented 58\% of the forest fragment (Table 2). 
Table 2. Absolute density ( $\mathrm{AD}$, ind. ha $\left.\mathrm{a}^{-1}\right)$, average height $(\mathrm{Ht}, \mathrm{m})$, diameter at breast height (DBH, $\left.\mathrm{cm}\right)$, and basic wood density (BWD, $\mathrm{g} \mathrm{cm}^{-3}$ ) of the species.

Tabela 2. Densidade absoluta (DA, ind. ha $\left.{ }^{-1}\right)$, altura média (Ht, m), diâmetro à altura do peito (DAP, $\left.\mathrm{cm}\right) \mathrm{e}$ densidade básica da madeira $\left(\mathrm{DBM}, \mathrm{g} \mathrm{cm}^{-3}\right)$ das espécies.

\begin{tabular}{lccccc}
\hline Species & Family & AD & Ht & DBH & BWD \\
\hline Helicostylis tomentosa (Poepp \& Endl.) J.F.Macbr. & Moraceae & 104 & 13.31 & 10.89 & 0.62 \\
Mabea occidentalis (Benth.) Müll. Arg. & Euphorbiaceae & 95 & 9.09 & 12.32 & 0.81 \\
Brosimum guianense (Aubl.) Huber & Moraceae & 77 & 13.88 & 13.41 & 0.82 \\
Parkia pendula (Willd) Benth. ex Walpers & Mimosaceae & 62 & 12.63 & 12.00 & 0.71 \\
Thyrsodium schomburgkianum Benth. & Anacardiaceae & 45 & 10.46 & 11.18 & 0.69 \\
Protium heptaphyllum (Aubl.) Marchand. & Burseraceae & 26 & 11.60 & 13.54 & 0.68 \\
Brosimum conduru Standl & Moraceae & 25 & 10.41 & 11.16 & 0.86 \\
Tapirira guianensis Aubl. & Anacardiaceae & 21 & 27.92 & 22.10 & 0.51 \\
Dialium guianensis (Aublet.) Sandw. & Caesalpiniaceae & 20 & 19.15 & 28.46 & 0.93 \\
Pouteria grandiflora (A.DC.) Baehni & Sapotaceae & 19 & 9.04 & 8.86 & 0.79 \\
\hline
\end{tabular}

Source: Espig et al. (2008).

\section{Carbon content}

In the forest fragment, 20 plots of $10 \mathrm{~m} \times 25 \mathrm{~m}\left(250 \mathrm{~m}^{2}\right)$ were determined and distributed systematically (Figure 1). Individuals were selected for leaf and wood sampling of each species to determine the $\mathrm{C}$ content.

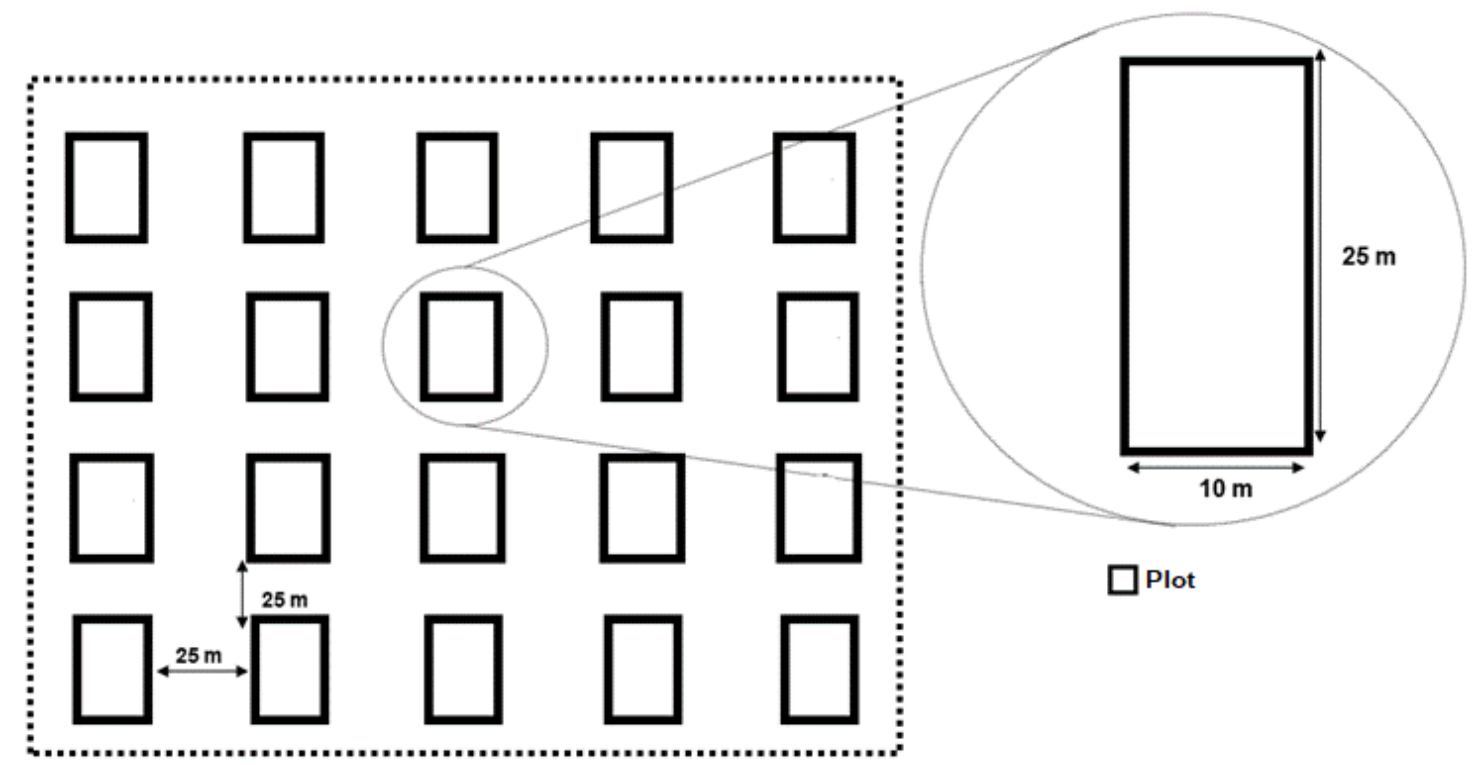

Figure 1. Sampling of plants used to collect leaves and wood.

Figura 1. Esquema de amostragem das plantas utilizadas para coleta de folhas e lenho.

Four healthy individuals were selected from each species. They were similar in size and vegetative development based on their height $(\mathrm{Ht})$ and diameter at breast height $(\mathrm{DBH})$ values (Table 2), representing the average of the other individuals. Of these, $\sim 500 \mathrm{~g}$ of fresh, healthy leaves in the four cardinal points (north, south, east, and west) of the upper middle third of treetops were sampled, as well as $\sim 50 \mathrm{~g}$ samples of wood, by direct measurement using an auger and a high-speed steel drill. There were four replications per component (leaves and wood) per species, totaling 80 samples for analysis of C content. All 80 samples were packed in identified paper bags and dried in an oven with renewal and air circulation at $65{ }^{\circ} \mathrm{C}$ until reaching constant weight for later determination of dry weight. The samples were ground in a Wiley mill, weighed, and introduced into porcelain crucibles. Then, they were taken to analysis of $\mathrm{C}$ levels by dry combustion in a LECO equipment, model C-144. 


\section{Statistical analysis}

The data were tested for normality and homoscedasticity, which are required for analysis of variance (ANOVA). The Shapiro-Wilk test (SHAPIRO; WILK, 1965) was used at a 95\% probability level.

For the $\mathrm{C}$ content of leaf and wood compartments between species, the data were submitted to ANOVA using the $\mathrm{F}$ test at a $95 \%$ probability level. When significant, the means were compared by ScottKnott test at a $95 \%$ probability level.

\section{RESULTS}

The levels of $\mathrm{C}$ in leaves varied between species (Figure 2). The species B. guianense presented the highest average leaf content $\left(456.7 \mathrm{~g} \mathrm{~kg}^{-1}\right)$ and $D$. guianensis presented the lowest $\left(451.4 \mathrm{~g} \mathrm{~kg}^{-1}\right)$. However, the leaf content of $\mathrm{C}$ of $D$. guianensis did not differ from the species $T$. schomburgkianum, H. tomentosa, $T$. guianensis, P. pendula, and M. occidentalis.

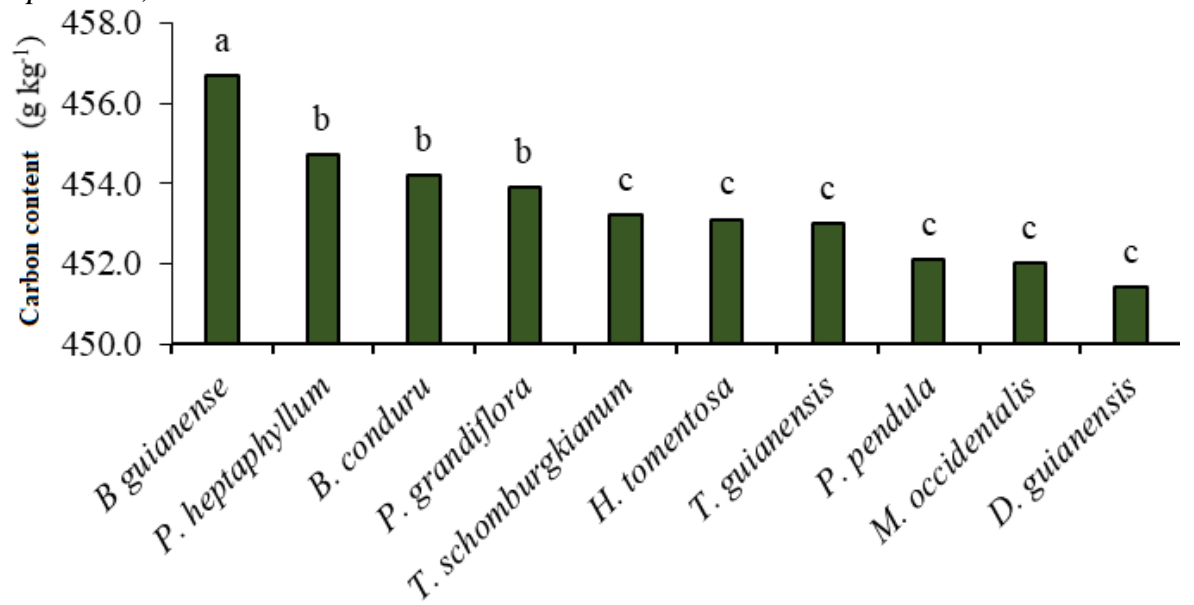

Figure 2. Carbon content in leaves of species with the highest absolute density in the Atlantic Forest fragment, Recife, Pernambuco, Brazil. Means followed by the same letter in columns do not differ by Scott Knott test at 5\% probability.

Figura 2. Teores de carbono nas folhas das espécies de maior densidade absoluta do fragmento florestal de Mata Atlântica, Recife, Pernambuco. Médias representadas pela mesma letra não diferem pelo teste de Scott-Knott a 5\% de probabilidade.

Considering the variation in $\mathrm{C}$ content in leaves of the ten species with the highest absolute density in the fragment, the group formed by the families Burseraceae, Moraceae, and Sapotaceae presented higher average concentrations of $\mathrm{C}$, differing from the other families (Figure 3).

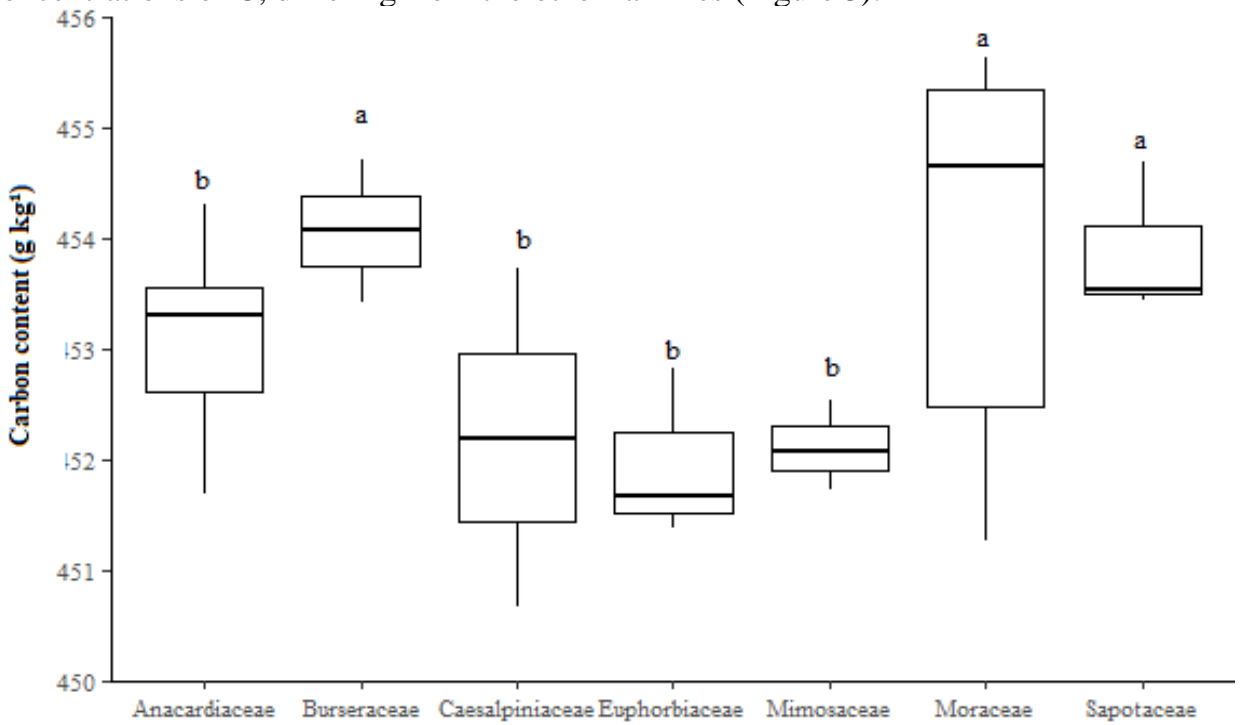

Figure 3. Carbon content in leaves of families of species with the highest absolute density in the Atlantic Forest fragment, Recife, Pernambuco, Brazil. Means followed by the same letter in columns do not differ by Scott Knott test at $5 \%$ probability. 
Figura 3. Teor de carbono nas folhas das famílias das espécies de maior densidade absoluta do fragmento florestal de Mata Atlântica, Recife, Pernambuco. Médias representadas pela mesma letra não diferem pelo teste de Scott-Knott a 5\% de probabilidade.

The $\mathrm{C}$ content of the wood of species varied between 451.7 and $456.8 \mathrm{~g} \mathrm{~kg}^{-1}$. P. heptaphyllum and M. occidentalis presented the highest and lowest levels, respectively (Figure 4). The C content in the wood of the species $P$. heptaphyllum and $P$. grandiflora differed significantly from the other species evaluated.

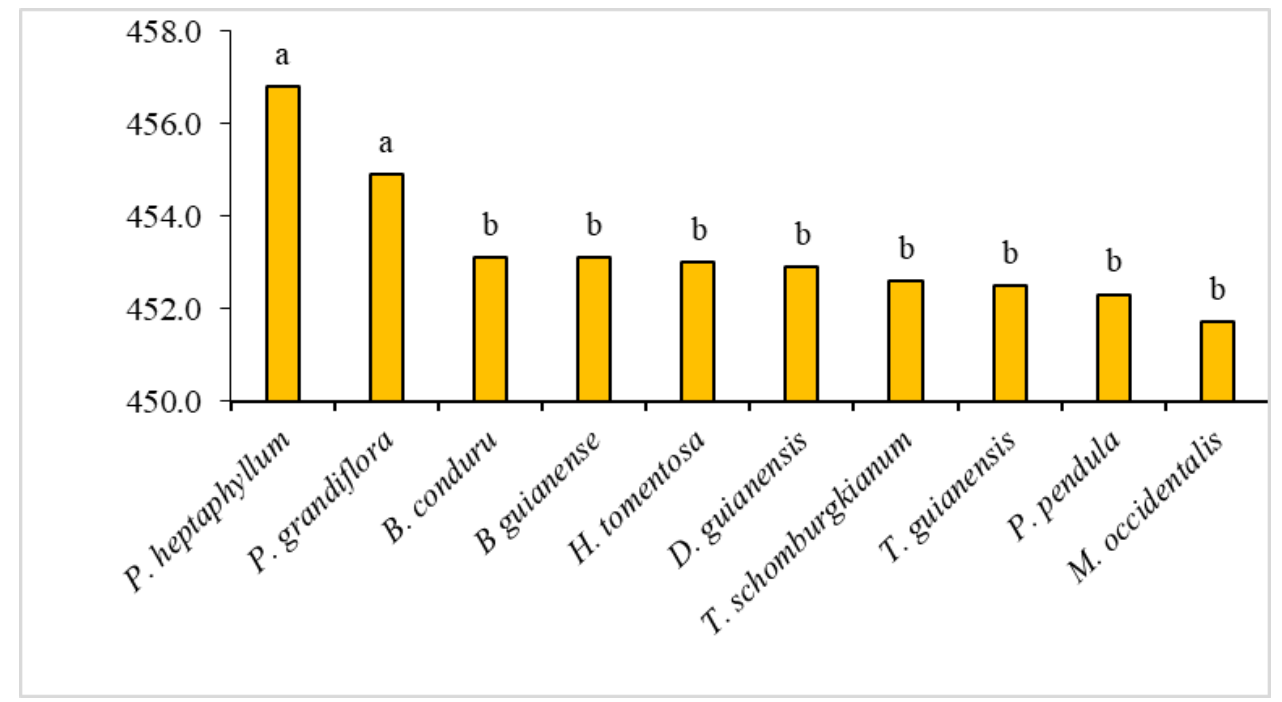

Figure 4. Carbon content in the wood of species with the highest absolute density in the Atlantic Forest fragment, Recife, Pernambuco, Brazil. Means followed by the same letter among species do not differ by Scott Knott test at $5 \%$ probability.

Figura 4. Teores de carbono no lenho das espécies de maior densidade absoluta do fragmento florestal de Mata Atlântica, Recife, Pernambuco. Médias representadas pela mesma letra entre as espécies não diferem pelo teste de Scott-Knott a 5\% de probabilidade.

Considering the variation in $\mathrm{C}$ content in the wood of the ten species with the highest absolute density in the fragment, the group formed by the families Burseraceae, Moraceae, and Sapotaceae presented higher average concentrations of $\mathrm{C}$, differing from the other families (Figure 5).

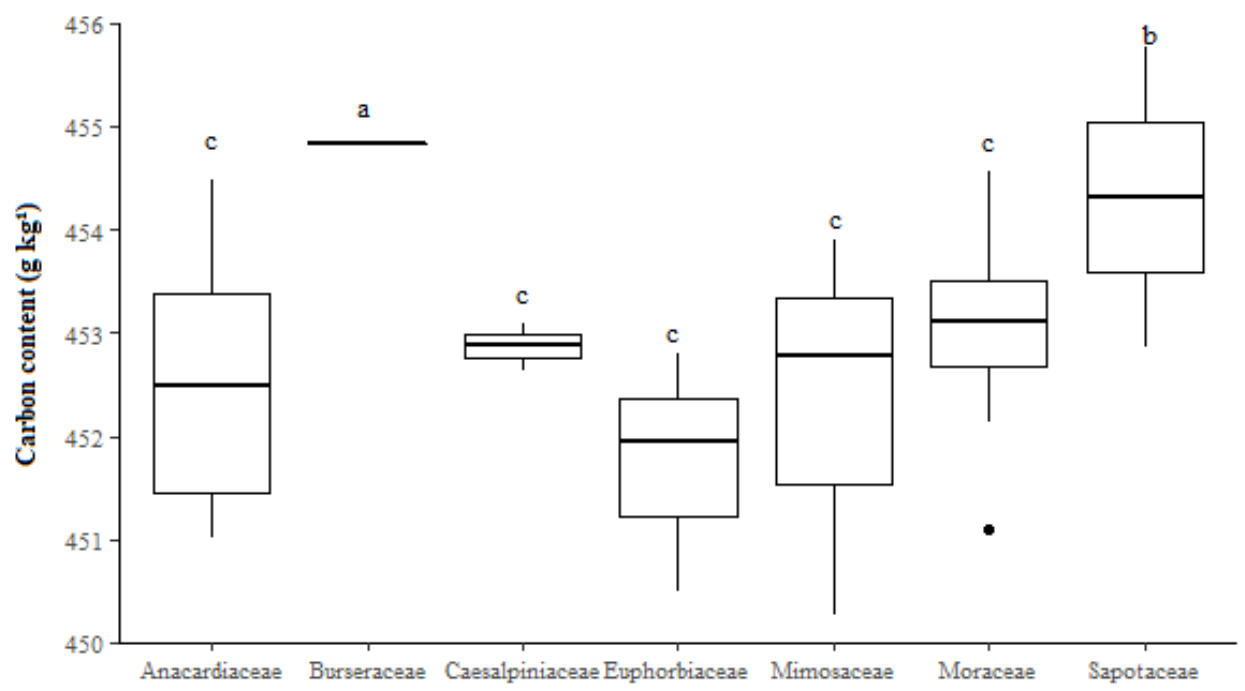

Figure 5. Carbon content in the wood of families of species with the highest absolute density in the Atlantic Forest fragment, Recife, Pernambuco, Brazil. Means followed by the same letter in columns do not differ by Scott Knott test at $5 \%$ probability.

Figura 5. Teores de carbono no lenho das famílias das espécies de maior densidade absoluta do fragmento florestal de Mata Atlântica, Recife, Pernambuco. Médias representadas pela mesma letra não diferem pelo teste de Scott-Knott a 5\% de probabilidade. 
On average, the concentration of $\mathrm{C}$ in the wood of species of the family Burseraceae was $456.76 \mathrm{~g}$ $\mathrm{kg}^{-1}$, a result $\sim 1 \%$ higher than the average of families with lower $\mathrm{C}$ levels $\left(452.50 \mathrm{~g} \mathrm{~kg}^{-1}\right)$. Although close, the difference between $\mathrm{C}$ levels given by the variability between species and families may affect the global $\mathrm{C}$ stock estimates.

The average $\mathrm{C}$ contents of the wood and leaf tissues of the Rainforest species did not differ from each other (Figure 6). On average, the wood fabric had a $\mathrm{C}$ content of $453.28 \mathrm{~g} \mathrm{~kg}^{-1}$ and the leaves had $453.43 \mathrm{~g} \mathrm{~kg}^{-1}$, with an average between wood and leaf of $453.36 \mathrm{~g} \mathrm{~kg}^{-1}$.

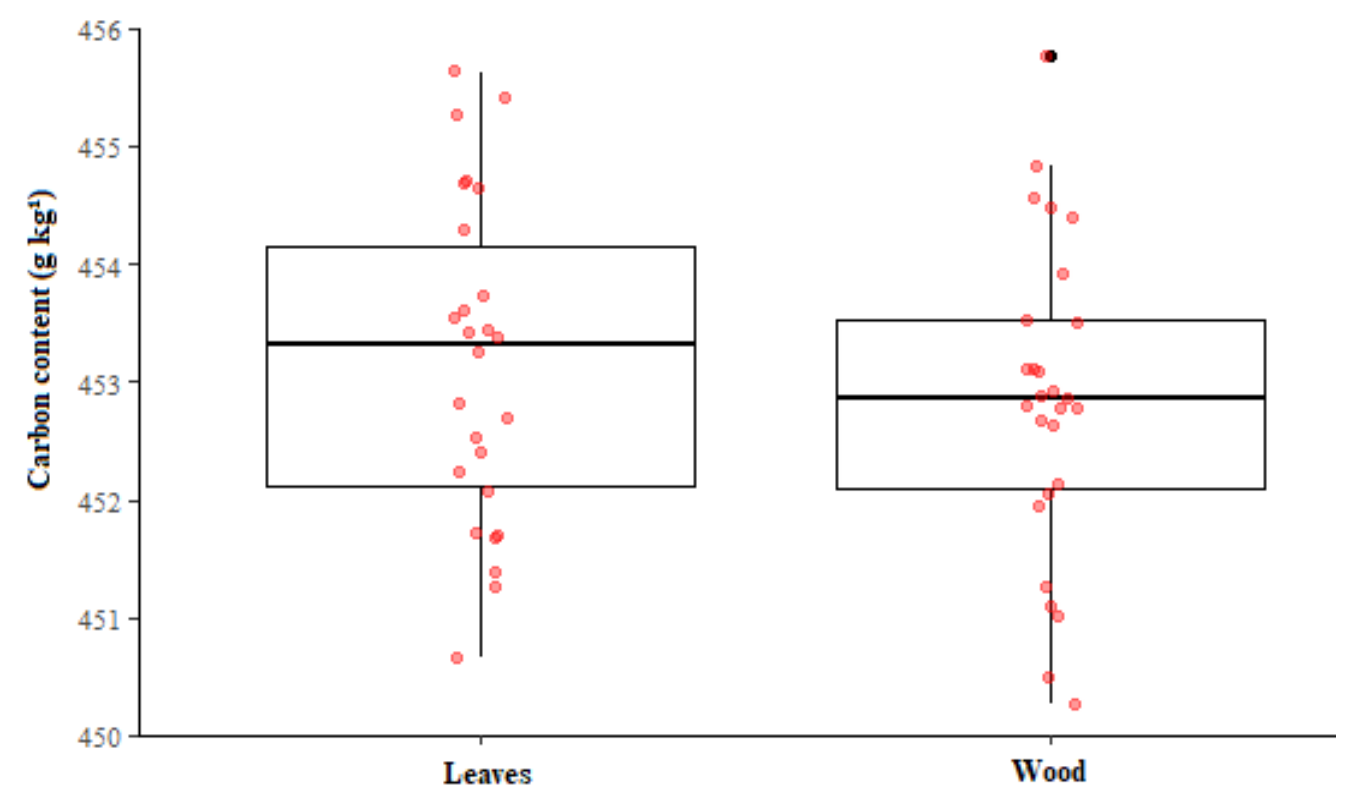

Figure 6. Average carbon content of forest species in the leaf and wood compartments of the Atlantic Forest fragment, Recife, Pernambuco, Brazil.

Figura 6. Teores médios de carbono das espécies florestais nos compartimentos folhas e lenho do fragmento florestal de Mata Atlântica, Recife, Pernambuco.

\section{DISCUSSION}

The results of this study show that the levels of $\mathrm{C}$ varied between 451.4 and $456.8 \mathrm{~g} \mathrm{~kg}^{-1}$ in the organs of the different species evaluated. This is consistent with the results of previous studies in the Atlantic Forest (MELLO CUNHA et al. 2009; VIEIRA et al., 2011; WATZLAWICK et al., 2012; WATZLAWICK et al., 2014).

According to Denardin et al. (2014), the different C concentrations are related to soil conditions and to the ability of each plant to fix this element through the biochemical cycle. Probably the lowest concentrations of C-rich components in leaves of the species T. schomburgkianum, H. tomentosa, T. guianensis, $P$. pendula and $M$. occidentalis and D. guianensis can explain these results.

The environmental conditions of the region and the physiological factors of each species affect the levels of $\mathrm{C}$ in leaves of forest species, but generally do not exceed $500 \mathrm{~g} \mathrm{~kg}^{-1}$ (WATZLAWICK et al., 2012 ; WATZLAWICK et al. , 2014; MA et al., 2018).

Watzlawick et al. (2012) observed average leaf levels of C in tree species of a Mixed Ombrophilous Forest lower than that of this study (423 g kg-1). Mello Cunha et al. (2009) found $443 \mathrm{~g} \mathrm{~kg}^{-1}$ of C in leaves of Atlantic Forest species in Rio de Janeiro, Brazil. Vieira et al. (2011) found similar results as those of this study in the Atlantic Forest in Rio de Janeiro. The values of $\mathrm{C}$ ranged between 450 and $459 \mathrm{~g} \mathrm{~kg}^{-1}$. The species evaluated by the authors were different from the species in this study. In addition, the different edaphoclimatic and morphophysiological conditions may explain the different levels observed.

The fixation of $\mathrm{C}$ in species varies according to the environmental conditions and intrinsic morphophysiological characteristics. Thus, the climatic conditions of the individual's area of occurrence and the type of species affected the allocation of C. Plants with similar ecophysiological characteristics are expected to present internally a similar behavior during the allocation process of C (POMPA-GARCÍA et al., 2017).

The common characteristics of the Burseraceae and Sapotaceae families are that species produce exudates, such as whitish latex, which are composed of proteins, starches, sugars, resins, and tannins 
(DAVID et al., 2019), which are rich in C and may have favored the highest concentrations compared to other families (POMPA-GARCÍA et al., 2017). The Euphorbiaceae family had the lowest average C content, which may be related to the low levels of resins and other C-rich components in leaves of species of this family.

The greatest variations in $\mathrm{C}$ levels within families were for the Moraceae family. This is probably related to differences in the chemical composition of cellulose, lignin, and hemicellulose in species of this family (GAO et al., 2016; MA et al., 2018).

The average $\mathrm{C}$ content in the wood of Rainforest species was $453.3 \mathrm{~g} \mathrm{~kg}^{-1}$. Mello Cunha et al. (2009) reported similar results: $453 \mathrm{~g} \mathrm{~kg}^{-1}$ of $\mathrm{C}$ for woody tissue of species of the Atlantic Forest in Rio de Janeiro, Brazil.

Despite the different floristic composition, soil type and climatic conditions of the areas of this study and the area studied by Mello Cunha et al. (2009), the studied families are common to both studies. Species with similar ecophysiological characteristics may behave similarly during the C allocation process (POMPAGARCÍA et al., 2017).

Organs with the highest concentration of $\mathrm{C}$ are associated with a high proportion of lignin, since it is the most abundant C-rich polymer in these plant tissues (MA et al., 2018). On the other hand, Gao et al. (2016) observed that volatile $\mathrm{C}$ levels in wood are the main drivers of the variation in the $\mathrm{C}$ content in species. The highest concentrations of C-rich components, such as volatile $\mathrm{C}$ and/or $\mathrm{C}$-structural compounds, in the wood of the species $P$. heptaphyllum and $P$. grandiflora may explain the higher levels found in these species.

In addition, $\mathrm{C}$ levels in the wood of forest species are closely related to size and age (MARTIN, THOMAS, 2013, JUSTINE et al., 2017, MA et al., 2019). This is related to the fact that, with the increase in age and DBH, the sapwood is converted into heartwood, leading to an increase in the proportion of heartwood in the wood and consequently in the levels of $\mathrm{C}$ in the tree (PINTO et al., 2004, HERRERO DE AZA et al., 2011).

Thus, more attention should be paid to the estimates of $\mathrm{C}$ stocks in forests mainly due to carbon differences between different families and different compartments of plant tissues that present variability in the proportions of phenolic compounds, extracts, lignin, and cellulose. Studies on C storage in the biomass of Atlantic Forest species are still scarce, and most of the existing ones consider fixed $\mathrm{C}$ levels for tropical forests varying between $47 \%$ and $50 \%$ of biomass.

Although there was no significant difference between the average $\mathrm{C}$ levels and the compartments in the Rainforest, the concentration of $\mathrm{C}$ in leaves tends to be higher than that in the wood. This is probably related to the high concentration of volatile compounds rich in $\mathrm{C}$ in leaves compared to other plant tissues, as highlighted by Yerena-Yamallel et al. (2011).

The results of this study suggest that the variation in the $\mathrm{C}$ content between species and families of tropical forests should be considered since the adoption of fixed values could lead to errors of overestimation of $\mathrm{C}$ stocks, which does not represent the reality and the magnitude of $\mathrm{C}$ sequestration by species in this ecosystem. In addition, these results suggest the use of specific $\mathrm{C}$ concentration estimates for different species and families as an alternative to pre-established values. This aims to avoid overestimating $\mathrm{C}$ stocks that may affect global $\mathrm{C}$ sequestration studies.

\section{CONCLUSIONS}

The results show that:

- The levels of $\mathrm{C}$ in leaves and in the wood of tree species in the tropical Rainforest differed between species and families. The Burseraceae, Moraceae, and Sapotaceae families show higher levels of C.

- $\quad$ The use of a pre-established $\mathrm{C}$ content $\left(500 \mathrm{~g} \mathrm{~kg}^{-1}\right)$ may generate inconsistent estimates that are higher than the real values for species and families in an Atlantic Forest environment. We suggest that $\mathrm{C}$ stock estimates use specific levels for species and/or families, contributing to a more realistic estimate of $\mathrm{C}$ storage patterns in the shoot biomass of Atlantic Forest species.

- These results contribute to a better understanding of $\mathrm{C}$ levels in species of the Atlantic Forest and provide data for the improvement of estimates of $\mathrm{C}$ stocks in these environments.

\section{REFERENCES}

ALVARES, C.A.; TAPE, J. L.; SENTELHAS, P. C.; GONÇALVES, J. L. M.; SPAROVEK, G. Köppen's climate classification map for Brazil. Meteorologische Zeitschrift, Stuttgart, v. 22, n. 6, p. 711-728, 2014.

BRAUN, M., FRITZ, D., WEISS, P., BRASCHEL, N., BÜCHSENMEISTER, R., FREUDENSCHUß, A., GSCHWANTNER, T., JANDL, R., LEDERMANN, T., NEUMANN, M., PÖLZ, W., SCHADAUER, K., 
SCHMID, C., SCHWARZBAUER, P., AND STERN, T.: A holistic assessment of greenhouse gas dynamics from forests to the effects of wood products use in Austria, Carbon Management, London, v. 7, n. 197, p. 271-283, 2016.

COLLINS, L., BRADSTOCK, R., XIMENES, F., HORSEY, B., SAWER, R., PENMAN, T. Above-ground forest carbon shows different responses to fire frequency in harvested and unharvested forests. Ecological Applications, Washington DC, v.29, n. 1815, 2019.

DAVID, E. S.; RABELO, E. M.; MARTINS, R. L.; ALMEIDA, S. S. M. S. Estudo fitoquímico, microbiológico, citotoxidade e antioxidante do látex Brosimum parinariodides spp. parinarioiides Ducke (Moraceae) com o Parahancornia amapa (Huber) Ducke (Apocinaceae). Biota Amazônia, Macapá, v. 9, n. 2, p. 16-20, 2019.

DENARDIN, R. B. N.; MATTIAS, J. L.; WILDNER, L. P.; NECI, C. N.; SORDI, A.; KOLLING, D. F.; BUSNELlO, F. J.; CERUTTI, T. Estoque de C no solo sob diferentes formações florestais. Ciência Florestal, Santa Maria, v. 24, n. 1, p. 59-69, 2014.

ESPIG, S.A.; FREIRE, F. J.; MARANGON, L. C.; FERREIRA, R. L. C.; FREIRE, M. B. G. S.; ESPIG, D. B. Composição e eficiência da utilização biológica de nutrientes em fragmento de Mata Atlântica em Pernambuco. Ciência Florestal, Santa Maria, v. 18, n. 3, p. 307-314, 2008.

FUNDAÇÃO SOS MATA ATLÂNTICA. Atlas dos remanescentes florestais da Mata Atlântica: período 2016-2017. São Paulo: Fundação SOS Mata Atlântica; São José dos Campos: Instituto Nacional de Pesquisas Espaciais. 2018.

GAO, B., TAYLOR, A. R., CHEN, H. Y. H., AND WANG, J. Variation in total and volatile carbon concentration among the major tree species of the boreal forest. Forest Ecology and Management, Netherlands, v. 375, p. 191-199, 2016.

HERRERO DE AZA, C., BELEN TURRION, M., PANDO, V., AND BRAVO, F. Carbon in heartwood, sapwood and bark along the stem profile in three Mediterranean Pinus species. Annals of Forest Science, Germany, v. 68, n. 6, p. 1067, 2011.

IPCC: Forest lands, Intergovernmental Panel on Climate Change Guidelines for National Greenhouse Gas Inventories. Institute for Global Environmental Strategies (IGES). Hayama, Japan, 2006.

LEWIS, S. L., LOPEZ-GONZALEZ, G., SONKE, B., AFFUM-BAFFOE, K., BAKER, T. R., OJO, L. O., PHILLIPS, O. L., REITSMA, J. M., WHITE, L., COMISKEY, J. A., DJUIKOUO, M. N., EWANGO, C. E. N., FELDPAUSCH, T. R., HAMILTON, A. C., GLOOR, M., HART, T., HLADIK, A., LLOYD, J., LOVETT, J. C., MAKANA, J. R., MALHI, Y., MBAGO, F. M., NDANGALASI, H. J., PEACOCK, J., PEH, K. S. H., SHEIL, D., SUNDERLAND, T., SWAINE, M. D., TAPLIN, J., TAYLOR, D., THOMAS, S. C., VOTERE, R., AND WOLL, H.: Increasing carbon storage in intact African tropical forests, Nature, United Kingdom, v. 457, p.1003-1006, 2009.

MA, S.; HE, F.; TIAN, D.; ZOU, D.; YAN, Z.; YANG, Y.; ZHOU, T. HUANG, K.; SHEN, H.; FANG, J. Variations and determinants of carbon content in plants: a global synthesis. Biogeosciences, Germany, [S.1.], v. 15, p. 693-702, 2018.

MA, S., EZIZ, A., TIAN, D., YAN, Z., CAI, Q., JIANG, M., JI, C., FANG, J. Tree size and age induced stem carbon content variations cause an uncertainty in forest carbon stock estimation. Biogeosciences Discussions Germany, p. 1-18, 2019.

MELlO CUNHA, G.; GAMA-RODRIGUES, A. C.; GAMA-RODRIGUES, E. F.; VELlOSO, A. C. X. Biomassa e estoque de carbono e nutrientes em florestas montanas da mata atlântica na região norte do estado do Rio de Janeiro. Revista Brasileira de Ciência do Solo, Viçosa, v. 33, n. 5, p. 1175-1185, 2009.

PEARSON, T. R. H.; BROWN, S.; MURRAY, L.; SIDMAN, G. Greenhouse gas emissions from tropical forest degradation: an underestimated source. Carbon Balance Management, United Kingdom, v. 12, n. 3, p. 1-11, 2017.

POMPA-GARCÍA, M.; SIGALA-RODRÍGUEZ, J. A.; JURADO, E.; FLORES, J. Tissue carbon concentration of 175 Mexican forest species. iForest - Biogeosciences and Forestry, Italy, [S.1.], v. 10, n. 4, p. 754-758, 2017.

REBOITA, M. S.; GAN, M. A.; ROCHA, R. P.; AMBRIZZI, T. Regimes de precipitação na América do Sul: uma revisão bibliográfica. Revista Brasileira de Meteorologia, Fortaleza, v. 25, n. 2, p. 185-204, 2010. 
SANTOS, H. G.; JACOMINE, P. K. T.; ANJOS, L. H. C.; OLIVEIRA, V. A.; LUMBRERAS, J. F.; COElHO, M. R.; ALMEIDA, J. A.; CUNHA, T. J. F.; OlIVEIRA, J. B. Sistema Brasileiro de Classificação de Solos. Rio de Janeiro: Embrapa, 2013, 353 p.

SAATCHI, S. S., HARRIS, N. L., BROWN, S., LEFSKY, M., MITCHARD, E. T., SALAS, W., PETROVA, S. (2011). Benchmark map of forest carbon stocks in tropical regions across three continents. Proceedings of the National Academy of Sciences, United States of America, v. 108, n. 24, p. 9899-9904, 2011.

SHAPIRO, S. S.; WILK, M. B. An analysis of variance test for normality (complete samples). Biometrika, Oxford, v. 52, n. 3/4, p. 591-611, 1965.

VASHUM, K. T.; JAYAKUMAR, S. Methods to estimate aboveground biomass and carbon stock in natural forests - a review. Journal of Ecosystem \& Ecography, [S.1.], v. 2, n. 4, p. 116-123, 2012.

VIEIRA, A. S.; ALVES, L. F.; DUARTE-NETO, P. J.; MARTINS, S. C.; VEIGA, L. G.; SCARANELLO, M. A.; PICOLlO, M. C.; CAMARGO, P. B.; CARMO, J. B.; SOUSA NETO, E.; SANTOS, F. A. M.; JOLY, C. A.; MARTINELLI, L. A. Stocks of carbon and nitrogen and partitioning between above-and belowground pools in the Brazilian coastal Atlantic Forest elevation range. Ecology and Evolution, United Kingdom, v. 1, n. 3, p. 421-434, 2011.

YERENA-YAMALLEL, J.; JIMÉNEZ-PÉREZ, J.; AGUIRRE-CALDERÓN, O. A.; TREVIÑO-GARZA, E. J. Concentración de carbono en la biomasa aérea del matorral espinoso tamaulipeco. Revista Chapingo serie ciencias forestales y del Ambiente, Chapingo, v. 17, n. 2, p. 283-291, 2011.

WATZLAWICK, L. F.; EBLING, A. A.; RODRIGUES, A. L.; VERES, Q. J. I.; LIMA, A. M. Variação nos teores de carbono orgânico em espécies arbóreas da floresta ombrófila mista. Floresta e Ambiente, Seropédica, v. 18, n. 3, p. 248-258, 2012.

WATZLAWICK, L. F.; MARTINS, P. J.; RODRIGUES, A. L.; EBLING, A. A.; BALBINOT, R.; LUSTOSA, S. B. C. Teores de carbono em espécies da Floresta ombrófila mista e efeito do grupo ecológico. Cerne, Lavras, v. 20, n. 4, p. 613-620, 2014. 